\title{
ASUPAN ZAT GIZI MAKRONUTRIEN PADA TODDLER
}

\author{
Peni Perdani Juliningrum \\ (Universitas Jember, Fakultas Keperawatan, Email: peni.psik@unej.ac.id)
}

\begin{abstract}
ABSTRAK
Nutrisi merupakan substansi organik yang dibutuhkan oleh tubuh toddler. Asupan zat gizi makronutrien dibutuhkan oleh tubuh sebagai penghasil energi. Energi yang dihasilkan ikut mempengaruhi status nutrisi anak. Tujuan penelitian adalah mengetahui gambaran asupan zat gizi makronutrien pada toddler di Kabupaten Jember. Penelitian ini memiliki design penelitian deskriptif dengan pendekatan crossectional. Jumlah sampel dalam penelitian ini adalah 30 responden dengan ibu yang memiliki anak berusia 1-3 tahun. Tekhnik pengambilan sampel menggunakan metode purposive sampling. Instrumen yang digunakan adalah kuesioner food recall 1×24 jam. Analisis data yang digunakan adalah analisis univariat.Sebagian besar anak toddler memiliki kecukupan zat makronutrien baik karbohidrat, lemak dan protein sebesar 93,3\%. Namun, 6,7\% anak memiliki kekurangan zat makronutrien. Tercukupinya kebutuhan energi dapat dipenuhi dengan makan makanan yang beraneka ragam serta mengkonsumsi bahan makanan yang memiliki kandungan sumber karbohidrat, protein dan lemak. Asupan zat gizi makronutrien yang tidak mencukupi kebutuhan tubuh dapat menyebabkan energi yang dihasilkan kurang dari energi yang dibutuhkan menyebabkan ketidakseimbangan energi sehingga gizi kurang dapat terjadi.
\end{abstract}

Kata Kunci : Nutrisi, Makronutrien, Toddler

\begin{abstract}
Nutrition is an organic substance needed by a toddler's body. Intake of macronutrient nutrients required by the body as an energy producer. The energy produced influences the nutritional status of children. The purpose of this study was to determine the description of macronutrient nutrient intake at the toddler in Jember Regency. This research method was a descriptive research design with a crossectional approach with a sample of 30 toddlers aged 1-3 years. The sampling technique used was a purposive sampling method. The instrument used was a 1x24 hour food recall questionnaire. The data analysis used was a univariate analysis. The result showed that most toddler children have adequate macronutrient substances, both carbohydrates, fats, and proteins of $93.3 \%$. However, $6.7 \%$ of children have a deficiency of macronutrient substances. The adequacy of energy needs can be met by eating a variety of foods and consuming foods that contain carbohydrate, protein, and fat sources. Intake of macronutrient nutrients that do not meet the body's needs can cause the energy produced less than the energy needed to cause energy imbalances so that malnutrition can occur.
\end{abstract}

Keywords: Nutrition, Macronutrients, Toddler 


\section{PENDAHULUAN}

Memenuhi nutrisi anak untuk mencegah malnutrisi menjadi salah satu target dari SDGs (Sustainable Development Gols) yang diharapkan dapat tercapai pada tahun 2030. Selama periode lima tahun pertama nutrisi merupakan faktor yang paling ikut mempengaruhi perkembangan pesat pada pertumbuhan fisik dan perkembangan otak anak. Bila di masa awal kehidupan, anak mengalami gangguan pada kebutuhan nutrisi maka kualitas kehidupan di masa depan ikut terpengaruh baik pertumbuhan fizik dan kualitas kecerdasan (Soetjiningsih, 2014 dan Adriani \& Wirjatmadi, 2014). Kandungan gizi makanan yang dikonsumsi balita sehari-hari perlu diberikan dengan kualitas baik serta dalam jumlah yang tepat, dimana nutrisi ini tidak hanya digunakan untuk aktivitas sehari-hari tapi juga dibutuhkan untuk pertumbuhan dan perkembangan selama periode tersebut.

Menurut Studi Diet Total (2014) sebanyak $101 \%$ adalah ratarata tingkat kecukupan energi pada balita diantaranya sebanyak $55,7 \%$ adalah balita dengan asupan energi yang kurang dari Angka Kecukupan Energi (AKE), sebanyak 17,1\% adalah balita dengan asupan energi lebih dari Angka Kecukupan Gizi (AKG) yang dianjurkan, yaitu $\geq$ $130 \%$ AKE, sebanyak 27,2\% kategori cukup, 48,9\% dalam kategori kurang dan 6,8\% kategori sangat kurang. Jika dilihat dari persentasi AKE terendah di NTT (92,3\%), sedangkan kecukupan energi yang melebihi angka nasional di Bali (101,1 \%). Dilihat dari prevalensi Angka Kecukupan
Protein, sebanyak 65,8\% balita mendapatkan asupan protein $\geq 100 \%$ AKP, $23,5 \%$ balita memperoleh $\leq$ $80 \%$ AKP, $10,6 \%$ balita memperoleh asupan protein $80-<100 \%$ (Kemenkes, 2016).

Kenaikan berat badan dapat digunakan menjadi salah satu indikator untuk menentukan status gizi. Menurut Profil Kesehatan Kabupaten Jember tahun 2014, di Kabupaten Jember, dari tahun 2009 2013 terjadi penurunan pada balita yang mengalami kenaikan berat badan. Sedangkan balita yang mengalami (BGM) dibawah garis merah cenderung mengalami penurunan (Dinkes, 2014). Hal ini menunjukkan banwa balita dengan gizi buruk masih ada di Kabupaten Jember.

Status gizi balita dapat ditentukan oleh makanan yang dikonsumsi. Konsumsi makanan yang beraneka ragam dan memiliki seimbang dapat memenuhi kecukupan gizi. Bahan makanan yang mengandung zat gizi makronutrien dapat membantu penyediaan energi yang dibutuhkan oleh tubuh. Bila kandungan makronutrien yang dimakan oleh balita kurang dari kebutuhan tubuh maka dapat mempengaruhi status nutrisi anak. Hal ini ditunjang oleh penelitian yang dilakukan oleh Diniyyah \& Nindya (2017) yang membuktikan bahwa energi, protein dan lemak ikut mempengaruhi status nutrisi anak. Ketidakseimbangan energi yang terjadi akibat dari ketidakseimbangan asupan makronutrien terhadap kebutuhan tubuh dapat menyebabkan perubahan jaringan dan massa tubuh sehingga terjadi penurunan berat badan balita (Barasi, 2009). Berdasarkan uraian tersebut, diperlukan penelitian 
mengenai gambaran asupan makanan yang mengandung makronutrien di Jember. Tujuan dari penelitian ini adalah untuk mengetahui gambaran asupan zat gizi makronutrien pada toddler di Kabupaten Jember.

\section{METODE PENELITIAN}

Penelitian ini memiliki design penelitian deskriptif dengan pendekatan crossectional. Sampel yang digunakan adalah Ibu dan anak toddler yang tinggal di area perkebunan kopi di 6 desa Kecamatan Panti Kabupaten Jember.
Tekhnik pengambilan sampel adalah metode purposive sampling. Kriteria inklusi anak adalah anak dengan usia 1-3 tahun dan tidak memiliki riwayat gangguan perkembangan secara medis sedangkan kriteria inklusi ibu adalah ibu dengan anak usia 1-3 tahun dan tidak memiliki riwayat gangguan perkembangan secara medis. Kriteria eksklusinya adalah ibu yang menolak untuk menjadi responden. Instrumen yang digunakan adalah kuesioner food recall $1 \times 24$ jam. Analisis data yang digunakan adalah analisis univariat.

\section{HASIL PENELITIAN} responden.

Hasil seleksi sampel yang sesuai dengan kriteria inklusi adalah 30

Tabel 1 Data Karakteristik Responden Ibu dan Anak di Kecamatan Panti Kabupaten Jember

\begin{tabular}{llc}
\hline Karakteristik Responden & & Anak 1-3 tahun \\
\hline \multicolumn{2}{l}{ Umur (rata-rata dalam Bulan) } & 27 \\
Jenis Kelamin Balita & Perempuan & $10(33,3 \%)$ \\
& Laki-laki & $20(66,7 \%)$ \\
Pendidikan Orang Tua & SD/Sederajat & $9(30 \%)$ \\
& SMP/Sederajat & $10(33,3 \%)$ \\
& SMA/Sederajat & $10(33,3 \%)$ \\
& Diploma/Lebih Tinggi & $1(3,4 \%)$ \\
Riwayat Pekerjaan Ayah & Meninggal & $1(3,3 \%)$ \\
& Wiraswasta & $3(10 \%)$ \\
Riwayat Pekerjaan Ibu & Kebun & $26(86,7 \%)$ \\
& Ibu Rumah Tangga & $28(93,8 \%)$ \\
Pendapatan per bulan & Wiraswasta & $2(6,7 \%)$ \\
& Rp 500.000 & $2(6,7 \%)$ \\
& RP 500.000 - Rp & $27(90 \%)$ \\
& 1.900 .000 & \\
& $>$ Rp 1.900.000 & $1(3,3 \%)$ \\
\hline
\end{tabular}

Pada tabel 1 menunjukkan karakteristik responden yang terlibat dalam penelitian ini adalah ibu dan anak. Usia rata-rata anak adalah 27 bulan. Sebagian besar pekerjaan kepala keluarga adalah bekerja di kebun dimana pendapatan per bulannya masih dibawah Upah Minimum Regional (UMR) (96,7\%). Sedangkan mayoritas pekerjaan ibu adalah ibu rumah tangga $(93,8 \%)$. 
Tabel 2 Distribusi Frekuensi Status Gizi Anak Toddler

\begin{tabular}{ccc}
\hline Status Gizi & f & $\%$ \\
\hline Gizi Kurang & 2 & $6,7 \%$ \\
Gizi Baik & 28 & $93,3 \%$ \\
\hline
\end{tabular}

Tabel 2 menunjukkan bahwa dari 30 anak toddler yang diukur status gizinya, ada anak yang mengalami status gizi baik dan gizi kurang.
Jumlah anak toddler yang mengalami gizi kurang sebanyak 2 orang $(6,7 \%)$, sedangkan yang berada pada status gizi baik sebanyak 28 orang $(93,3 \%)$.

Tabel 3 Distribusi Frekuensi Balita Berdasarkan Asupan Zat Gizi Makronutrien

\begin{tabular}{lcc}
\hline \multicolumn{1}{c}{ Asupan } & $\mathrm{f}$ & $\%$ \\
\hline Asupan Karbohidrat & 28 & 93,3 \\
Baik & 2 & 6,7 \\
Kurang & - & - \\
Lebih & & \\
Asupan Protein & 28 & 93,3 \\
Baik & 2 & 6,7 \\
Kurang & - & - \\
Lebih & & \\
Asupan Lemak & 28 & 93,3 \\
Baik & 2 & 6,7 \\
Kurang & - & \\
Lebih & & \\
\hline
\end{tabular}

Pada tabel 3 menunjukkan bahwa sebagian besar anak toddler memiliki kecukupan zat makronutrien baik karbohidrat, lemak dan protein sebesar 93,3\%. Namun, ada 2 anak yang memiliki kekurangan zat makronutrien.

\section{PEMBAHASAN}

Periode penting dalam tumbuh kembang anak adalah masa balita karena pada masa ini merupakan dasar yang akan mempengaruhi pertumbuhan dan perkembangan anak selanjutnya. Sehingga apabila pada masa ini anak mengalami sedikit saja kelainan seperti kelainan gizi dan tidak tertangani dengan baik, maka akan mempengaruhi kualitasnya di masa pra sekolah, sekolah, akil baliq dan remaja. Terdapat perbedaan pertumbuhan pada balita yang mengalami gangguan pertumbuhan dengan balita yang pertumbuhannya normal. Pada awalnya yaitu usia bayi, balita normal dan balita dengan gangguan pertumbuhan mengalami tingkatan pertumbuhan yang sama. Namun, akan terjadi perbedaan pertumbuhan saat usia balita. Balita yang mendapatkan asupan gizi kurang baik akan mengalami gangguan pertumbuhan atau pertumbuhannya tidak seperti pertumbuhan balita yang tercukupi gizinya (Adriani\&Wirajatmadi, 2014). Salah satu yang menjadi 
kebutuhan gizi balita adalah makronutrien.

Makronutrien merupakan nutrisi terdiri dari karbohidrat, lemak dan protein yang menyediakan kalori atau energi yang dibutuhkan untuk menjaga fungsi tubuh serta menjalankan aktivitas kehidupan sehari-hari (WHO, 2019). Indikator balita tercukupi energinya adalah berat badan yang normal. Gizi kurang pada balita dapat disebabkan karena kebutuhan gizi yang tidak mencukupi kebutuhan balita atau konsumsi energi melalui makanan yang mengandung makronutien kurang dari energi yang dikeluarkan (Andriani \& Wirjatmadi, 2014 ; Cakrawati \& Mustika, 2014).

Seiring dengan bertambahnya usia, kebutuhan akan makronutrien semakin meningkat untuk memenuhi kebutuhan metabolisme tubuh. Dari hasil penelitian ini menunjukkan sebagian besar anak toddler telah tercukupi asupan karbohidratnya. Sumber karbohidrat yang dikonsumsi anak adalah nasi. Karbohidrat merupakan sumber energi utama tubuh yang diperlukan anak yang sedang tumbuh. Kandungan optimalnya dalam makanan adalah berkisar antara 40-60\% dari jumlah energi. Jenis karbohidrat yang sebaiknya dimakan oleh toddler terdiri dari polisakarida seperti gandum, beras, kentang (Adriani\&Wirajatmadi, 2014).

Asupan protein pada sebagian besar toddler yang ditunjukkan pada tabel 3 telah tercukupi dengan baik. Protein merupakan sumber energi dan sumber asam amino esensial yang digunakan oleh tubuh sebagai zat pembangun seperti pertumbuhan dan sebagai zat pembentukan protein, hemoglobin, enzim, hormon dan antibodi, mengganti sel tubuh yang rusak serta dapat berfungsi sebagai pemelihara keseimbangan asam basa cairan tubuh (Almatsier, 2010 dan Adriani \& Wirjatmadi, 2014). Bila asupan protein kurang dari kebutuhan tubuh maka sistem imunitas tubuh toddler dapat menurun sehingga mudah mengalami penyakit infeksi (Rahim, 2014).

Jumlah protein yang dianggap adekuat adalah jenis protein hewani karena mudah dicerna dan diserap oleh tubuh serta berkualitas tinggi (Adriani \& Wirjatmadi, 2014). Pada penelitian ini asupan protein yang dimakan oleh toddler berjenis protein hewani dan nabati. Jenis protein hewani yang sering dimakan dan dapat dibeli oleh keluarga adalah telur ayam, sedangkan ikan dan daging jarang bahkan tidak pernah dimakan karena harganya yang tidak dapat keluarga beli. Sedangkan protein nabati yang sering dimakan oleh toddler adalah tahu dan tempe.

Lemak berfungsi juga sebagai sumber energi serta pelarut vitamin. Lemak yang ada pada tubuh diperoleh dari 2 sumber yaitu sumber makanan dan hasil produksi organ hati. Kebutuhan lemak dianjurkan $15-20 \%$ dari energi total. Pada umumnya hidangan makanan di Indonesia telah mencukupi kebutuhan lemak. Hal ini juga dapat terlihat pada tabel 3 bahwa 93,3\% makanan yang dimakan anak toddler telah mencukupi kebutuhan lemak. Kurangnya asupan lemak dapat menyebabkan energi yang dihasilkan juga ikut berkurang sehingga terjadi perubahan massa dan jaringan tubuh toddler (Barasi, 2009).

Pada tabel 3 menunjukkan $6,7 \%$ anak toddler tidak tercukupi asupan karbohidrat, lemak dan protein. Ketidaktercukupinya asupan 
zat gizi makronutrien menyebabkan energi yang dihasilkan kurang dari energi yang dibutuhkan sehingga menyebabkan ketidakseimbangan energi maka gizi kurang dapat terjadi (Barasi, 2009). Hal ini dapat tunjukkan pada tabel 2 bahwa 6,7\% anak toddler mengalami status gizi kurang. Salah satu yang menjadi penyebab kurangnya asupan gizi makronutrien adalah ketidakmampuan secara ekonomi dari keluarga dalam membeli bahan makanan sumber karbohidrat, lemak dan protein, hal ini terlihat pada tabel 1 yang menunjukkan 6,7\% keluarga memiliki pendapatan Rp 500.000/bulan. Hal ini sejalan dengan penelitian yang dilakukan oleh Lutviana \& Budiono (2010) bahwa pendapatan keluarga mempengaruhi konsumsi makanan sehari-hari sehingga kondisi ini mempengaruhi status gizi anak.

\section{SIMPULAN}

Makanan yang dikonsumsi oleh toddler adalah makanan yang mengandung sumber zat energi agar dapat melaksanakan aktivitas seharihari seperti bermain, belajar dan kegiatan lainnya. Kecukupan energi juga penting bagi toddler agar diperoleh tumbuh kembang yang optimal. Tercukupinya kebutuhan energi dapat dipenuhi dengan makan makanan yang beraneka ragam serta mengkonsumsi bahan makanan yang mengandung sumber karbohidrat, protein dan lemak.

\section{SARAN}

Makanan yang perlu
dikonsumsi oleh toddler adalah
makanan yang beraneka ragam yang

dapat memenuhi kecukupan energi agar nutrisi balita terpenuhi.

\section{DAFTAR PUSTAKA}

Adriani, Merryana dan Wirjatmadi, Bambang. (2014). Peranan Gizi dalam Siklus Kehidupan. Jakarta: Kencana Prenadamedia Group

Almatsier, S. (2010). Prinsip Dasar Ilmu Gizi. Jakarta: PT Gramedia Pustaka Utama.

Barasi, M., Nutrition At A Glance. Penerjemah: Hermin. (2009). At A Glance : Ilmu Gizi. Jakarta: Erlangga. 2007.

Cakrawati, Dewi dan Mustika. (2014). Bahan Pangan, Gizi dan Kesehatan. Bandung:Alfabeta

Dinas Kesehatan Jember. (2014). Profil Kesehatan Kabupaten Jember. Available from http://www.depkes.go.id/resource s/download/profil/PROFIL_KAB _KOTA_2014/3509_Jatim_Kab_J ember_2014.pdf

Diniyyah, S.R. : Nindya, T.S. (2017). Asupan Energi, Protein dan Lemak dengan Kejadian Gizi Kurang pada Balita Usia 24-59 Bulan di Desa Suci, Gresik. Jurnal Amerta Nutrition: 341-350

Kemeterian Kesehatan. 2016. Situasi Gizi di Indonesia. Available from http://www.kemkes.go.id/develop ment/resources/download/tabloid/ infodatin/infodatin-gizi-2016.pdf

Lutviana, E.; Budiono, I. (2010). Prevalensi Dan Determinan Kejadian Gizi Kurang Pada 
Balita. Jurnal Kesehatan Masyarakat 5(2):138-144.

Rahim, K.F. Faktor Resiko

Underweight Balita Umur 7 - 59

Bulan. Jurnal Kesehatan

Masyarakat. 2014;9(2):115- 121
Soetjiningsih. (2014). Tumbuh Kembang Anak. Edisi 2. Jakarta: EGC

World Health Organization. Macronutrients. Available from http://www.emro.who.int/healthtopics/macronutrients/index.html 